\title{
Down regulation of peroxisome proliferator-activated receptor $\gamma$ expression by inflammatory cytokines and its reversal by thiazolidinediones
}

\author{
T. Tanaka, H. Itoh, K. Doi, Y. Fukunaga, K.Hosoda, M. Shintani, J. Yamashita, T.-H. Chun, M. Inoue, \\ K. Masatsugu, N.Sawada, T.Saito, G. Inoue, H. Nishimura, Y. Yoshimasa, K. Nakao \\ Department of Medicine and Clinical Science, Kyoto University Graduate School of Medicine, Sakyouku, Kyoto, Japan
}

\begin{abstract}
Aims/hypothesis. Previous studies show that inflammatory cytokines play a part in the development of insulin resistance. Thiazolidinediones were developed as insulin-sensitizing drugs and are ligands for the peroxisome proliferator-activated receptor $\gamma$ $(\operatorname{PPAR} \gamma)$. We hypothesized that the anti-diabetic mechanism of thiazolidinediones depends on the quantity of PPAR $\gamma$ in the insulin resistant state in which inflammatory cytokines play a part.

Methods. We isolated rat PPAR $\gamma 1$ and $\gamma 2 \mathrm{cDNAs}$ and examined effects of various cytokines and thiazolidinediones on PPAR $\gamma$ mRNA expression in rat mature adipocytes.

Results. Various inflammatory cytokines, such as tumour necrosis factor- $\alpha$ (TNF- $\alpha$ ), interleukin-1 $\alpha$ (IL$1 \alpha)$, IL-1 $\beta$, IL-6 and leukaemia inhibitory factor decreased PPAR $\gamma$ mRNA expression. In addition, hydrogen peroxide, lysophosphatidylcholine or phorbol 12-myristate 13-acetate also decreased the expression
\end{abstract}

of PPAR $\gamma$. The suppression of PPAR $\gamma$ mRNA expression caused by $10 \mathrm{nmol} / \mathrm{l}$ of TNF- $\alpha$ was reversed $60 \%$ and $55 \%$ by treatment with $10^{-4} \mathrm{~mol} / \mathrm{l}$ of troglitazone and $10^{-4} \mathrm{~mol} / \mathrm{l}$ of pioglitazone, respectively. The suppression of glucose transporter $4 \mathrm{mRNA}$ expression caused by TNF- $\alpha$ was also reversed by thiazolidinediones. Associated with the change of $\operatorname{PPAR} \gamma$ mRNA expression, troglitazone improved glucose uptake suppressed by TNF- $\alpha$.

Conclusion/interpretation. Our study suggests that inflammatory cytokines could be factors that regulate PPAR $\gamma$ expression for possible modulation of insulin resistance. In addition, we speculate that the regulation of PPAR $\gamma$ mRNA expression may contribute to the anti-diabetic mechanism of thiazolidinediones. [Diabetologia (1999) 42: 702-710]

Keywords Cloning, $\operatorname{PPAR} \gamma$, insulin resistance, thiazolidinediones, cytokines, TNF- $\alpha$, rat, adipocyte, glucose uptake.
Received: 11 August 1998 and in final revised form: 12 February 1999

Corresponding author: H. Itoh M.D. Ph.D., Department of Medicine and Clinical Science/Kyoto University Graduate School of Medicine, 54 Shogoin Kawahara-cho, Sakyouku, Kyoto 606, Japan

Abbreviations: 8-Br-cAMP, 8-Bromoadenosine-3':5' -cyclicmonophosphate; 8-Br-cGMP, 8-bromoadenosine-3':5'-cyclicmonophosphate; cDNA, complementary DNAs; GLUT4, glucose transporter $4 ; \mathrm{H}_{2} \mathrm{O}_{2}$, hydrogen peroxide; LIF, Leukemia inhibitory factor; LPL, lipoprotein lipase; Lyso-PC, lysophosphatidylcholine; PMA, phorbol 12-myristate 13-acetate; $\operatorname{PPAR} \gamma$, peroxisome proliferator-activated receptor; RT-PCR, reverse transcription-PCR.
Impairment of insulin action (insulin resistance) is frequently observed in Type II (non-insulin-dependent) diabetes mellitus as well as in wasting syndromes including neoplastic, inflammatory and chronically infectious diseases $[1,2]$. Previous studies suggest that inflammatory cytokines, such as tumour necrosis factor- $\alpha$ (TNF- $\alpha$ ) [3], interleukin-1 (IL-1) [4], IL-6 [5], leukaemia inhibitory factor (LIF) [6] and transforming growth factor- $\beta$ (TGF- $\beta$ ) [7] are involved in the development of insulin resistance. Clinical studies have shown that TNF- $\alpha$ and IL- 6 concentrations are increased in the sera of patients with several cancers and infectious diseases, in which insulin action is impaired [8]. Moreover, infusion of rats 
with TNF- $\alpha$ is reported to result in pronounced insulin resistance [9].

Thiazolidinediones are a new class of drugs that increase sensitivity to insulin [10]. They lower plasma insulin concentrations and enhance insulin action in obese diabetic animals [11]. In Type II diabetic patients, thiazolidinediones reduce basal and postprandial blood glucose values as well as $\mathrm{HbA}_{1 \mathrm{c}}$ and fructosamine values [10]. Recently, thiazolidinediones have been shown to be the ligands for the peroxisome proliferator-activated receptor (PPAR) $\gamma$, an orphan member of the nuclear receptor superfamily of ligand-activated transcription factors [12], which has been recognized to be the functional receptor in anti-diabetic action of thiazolidinediones. However, the exact linkage between PPAR $\gamma$ activation and an improvement of insulin resistance by thiazolidinediones has not been fully explained.

We hypothesize that the anti-diabetic mechanism of thiazolidinediones depends on the quantity of PPAR $\gamma$ mRNA in the insulin resistant state especially in the state where inflammatory cytokines play a part. Our study was therefore designed to determine whether inflammatory cytokines change PPAR $\gamma$ mRNA expression and, if so, whether thiazolidinediones restore the activity of inflammatory cytokines on PPAR $\gamma$ mRNA expression. To answer these questions, we first isolated rat PPAR $\gamma 1$ and PPAR $\gamma 2$ cDNAs and examined the effect of various inflammatory cytokines and also some intracellular signalling factors on the regulation of PPAR $\gamma$ mRNA expression in cultured rat mature adipocytes. We further investigated the effect of thiazolidinediones on the regulation of PPAR $\gamma$ in the presence of TNF- $\alpha$.

\section{Materials and methods}

Molecular cloning of rat PPAR $\gamma 1$ and $\gamma 2$ complementary $D N A s$ (cDNAs). Complementary DNAs for PPAR $\gamma 1$ and $\gamma 2$ were prepared by the reverse transcription-polymerase chain reaction (RT-PCR). Using a DNA synthesizer (model 381A; Applied Biosistems, Foster City, Calif., USA), three oligonucleotide primers P-1 (5'-ACAAGACTACCCTTTACTGAAATTACC-3'), P-2 (5'-TACAGCAAATCTCTGTTTTATGCTGTT- $\left.3^{\prime}\right)$ and P-3 (5'-ATTTCTTAGGTGTCAGATTTTTTTCCCTCA-3') were synthesized which are based on the published mouse PPAR $\gamma 1$ and $\gamma 2$ sequences [13]. Primer P-1 consisted of the 27 nucleotides upstream of the mouse PPAR $\gamma 1$ ATG initiator Met. Primer P-2 also consisted of the nucleotides upstream of the mouse PPAR $\gamma 2$ ATG initiator Met. Primer P-3 possessed the complement to the terminal 30 nucleotides downstream of the mouse sequence common to PPAR $\gamma 1$ and $\gamma 2$. The primer pairs P-1/P-3 and P-2/P-3 were used in PCR reactions to generate full length rat cDNAs for $\operatorname{PPAR} \gamma 1$ and PPAR $\gamma 2$, respectively. First-stranded cDNAs were synthesized from $10 \mu \mathrm{g}$ of total RNA from Sprague-Dawley rats epididymal fat pads by the oligo (dT)-primed reverse transcription (Superscript, Gibco, Grand Island, N. Y., USA) and subjected to the PCR (KOD Dash; Toyobo, Osaka, Japan). The reaction profile was as follows: denaturation at $94^{\circ} \mathrm{C}$ for $30 \mathrm{~s}$, annealing at $52^{\circ} \mathrm{C}$ for $2 \mathrm{~s}$ and extension at $74^{\circ} \mathrm{C}$ for $30 \mathrm{~s}$ for 30 cycles. The PCR products of predicted size were isolated and further subcloned into pGEM-T vector (Promega, Madison, Wis., USA) for sequencing.

DNA sequencing. Sequence determination of subcloned PCR products was carried out by the dideoxy chain termination method using Sequenase version 2.0 (U.S. Biochemical, Cleveland, Ohio, USA). Direct sequencing of the RT-PCR products was also done using PRISM sequenase fluorescent dye-labelled dideoxynucleotide kit (Applied Biosystems, Foster City, Calif., USA). All DNA sequences were confirmed by reading both DNA strands.

Isolation of rat mature adipocytes and cell incubation. Male Sprague-Dawley rats (200 g, Shimizu Experimental Supplies, Kyoto, Japan) were used throughout. The epididymal fat pads were removed, minced and digested with collagenase (type 2, Sigma Chemical, St. Louis, Mo., USA) for $60 \mathrm{~min}$. at $37^{\circ} \mathrm{C}$ under continuous shaking (150 cycles per minute). The dispersed tissues were filtered through a nylon mesh with a pore size of $250 \mu \mathrm{m}$ and centrifuged, thereby giving rise to floating mature adipocytes [14]. The mature adipocytes were incubated in DMEM with $5 \%$ bovine serum albumin, $500 \mathrm{IU} / \mathrm{ml}$ penicillin and $500 \mu \mathrm{g} / \mathrm{ml}$ streptomycin at $37^{\circ} \mathrm{C}$ in $5 \% \mathrm{CO}_{2}$ for the time indicated in the figures with or without the following agents: recombinant human TNF- $\alpha$, human IL-1 $\alpha$ (Dainihon Pharmaceutical, Osaka, Japan), rat IL- $1 \beta$, rat IL-6, human LIF (Immugenex, Los Angeles, Calif., USA), porcine TGF- $\beta$ (R \& D Systems, Minneapolis, Minn., USA), 8-bromoadenosine$3^{\prime}: 5^{\prime}$-cyclic-monophosphate (8-Br-cAMP), 8-bromoguanosine-3':5'-cyclic-monophosphate (8-Br-cGMP), phorbol 12myristate 13-acetate (PMA), lysophosophatidylcholine (LysoPC) (Sigma Chemical), hydrogen peroxide $\left(\mathrm{H}_{2} \mathrm{O}_{2}\right)$ (Kanto Chemical, Tokyo, Japan), troglitazone (Sankyo, Tokyo. Japan), pioglitazone (Takeda Chemical Industries, Osaka, Japan). As the compounds used in the study were solubilized in DMSO, control cells were treated with matching concentrations of DMSO, and the final concentrations of DMSO were kept below $0.05 \%$. Our culture medium did not contain insulin or cortisol.

Northern blot analysis. Northern blot analysis was done as described [15] using ${ }^{32} \mathrm{P}$-labelled cDNA probes. Rat PPAR $\gamma 1$ cDNA fragments subcloned into pGEM-T vectors were digested with HincII and EcoRI and the resulting inserts (744 bp long) used as probes common to PPAR $\gamma 1$ and $\gamma 2$ mRNA expression. The cDNA probe for glucose transporter 4 (GLUT4) [16] was obtained from G. I. Bell (University of Chicago, Ill., USA). A human $\beta$-actin genomic probe (Wako Pure Chemical, Osaka, Japan) was used to monitor the amount of total RNA in each sample. The cDNA probe for lipoprotein lipase (LPL) and $o b$, the gene for leptin, were obtained using the polymerase chain reaction as described previously [17]. Messenger RNA expression for PPAR $\gamma$ and GLUT4 were normalized to $\beta$-actin mRNA expression and given as percent of the values detected in the control cultured rat adipocytes for the respective genes.

Reverse transcription and amplification of $c D N A s$. Of the total RNA $0.1 \mu \mathrm{g}$ was reverse-transcribed. The transcribed cDNA was then used for PCR amplification to estimate the expression of rat $\operatorname{PPAR} \gamma 1, \operatorname{PPAR} \gamma 2$, rat TNF- $\alpha$ receptor (mouse TNF- $\alpha$ receptor type I homologue) [18] and $\beta$-actin. The PPAR $\gamma 1$ primer pair P-1 and P-4 (5'-GTCTTCATAGTGTGGAGC AGAAATGCTG-3') generates a fragment of $177 \mathrm{bp}$, which is based on our rat PPAR $\gamma 1$ sequence. The PPAR $\gamma 2$ 




Fig. 1. The nucleotide and deduced amino acid sequences of rat $\operatorname{PPAR} \gamma 1$ and $\gamma 2$ cDNAs. The Met at amino acid residue 31 is the initiator Met for PPAR $\gamma 1$. The translation stop codon is indicated by $* * *$

primer pair P-2 and P-4 generates a fragment of $267 \mathrm{bp}$, which is based on the rat PPAR $\gamma 2$ sequence we cloned. The $\beta$-actin primer pair (5'-TGGAGAAGAGCTATGAGCTGCCTG$\left.3^{\prime}\right)$, (5'-GTGCCACCAGACAGCACTGTGTTG-3') generates a fragment of $201 \mathrm{bp}$. The rat TNF- $\alpha$ receptor primer pair (5'-GGTGACCGGGAGAAGAGGGATAAT-3'), (5'GA ATCCGCGTGGCAGTTACACAC- $3^{\prime}$ ) generates a fragment of $411 \mathrm{bp}$.

Glucose uptake in rat mature adipocytes. Uptake of 2-deoxyglucose by mature adipocytes was measured as described previously [19]. Briefly, cells were incubated with the test agents for $24 \mathrm{~h}$ in DMEM with $5 \%$ bovine serum albumin before the assay. The $100 \mu \mathrm{l}$ of adipocyte cell suspension was pipetted into minisorp tube (Nunc, Roskilde, Denmark) and incubated in the presence or absence of insulin $\left(10^{-7} \mathrm{~mol} / \mathrm{l}\right)$. After $30 \mathrm{~min}$ of incubation, $50 \mu \mathrm{l}$ of 2 -deoxy-D- ${ }^{3} \mathrm{H}$-glucose 


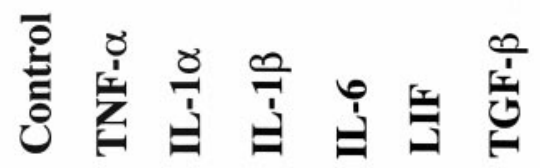

PPAR $\gamma$



\section{$\beta$-actin}

A

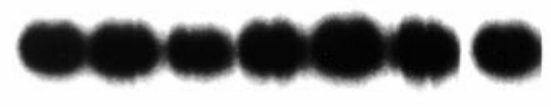



$\operatorname{PPAR} \gamma 1$

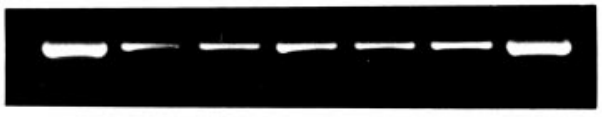

$\operatorname{PPAR} \gamma 2$

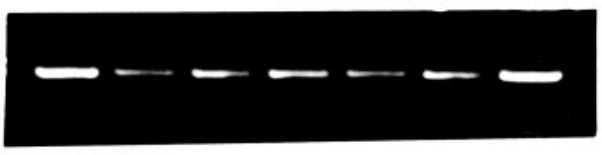

$\beta$-actin

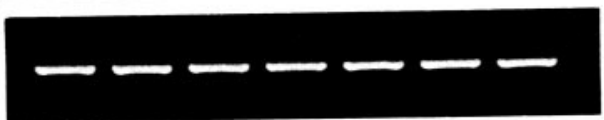

B

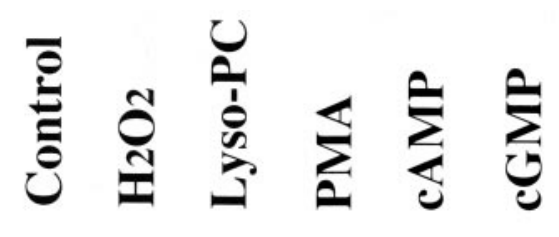

$\operatorname{PPAR} \gamma$



\section{$\beta$-actin}

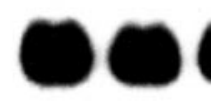

C $\left(0.625 \mu \mathrm{Ci} / \mathrm{ml}: 2.315 \times 10^{4} \mathrm{Bg} / \mathrm{ml}\right)$ was added and the incubation continued for another $6 \mathrm{~min}$ at $37^{\circ} \mathrm{C}$. Glucose uptake was stopped by addition of cytochalasin B (Sigma Chemical). Samples of cells were separated from the incubation medium by centrifugation through dinonyl phthalate oil, and then the amounts of radioactivity of separated cells were determined by liquid scintillation counting. The non-specific rate of 2-deoxyglucose uptake was obtained by adding cytochalasin B prior to the addition of the labelled 2-deoxyglucose solution to the cells. The net uptake of 2-deoxyglucose was then calculated.

Statistical analysis. All results were expressed as means \pm SEM ( $n=4$ to 9$)$. Statistical analysis of the data was done using ANOVA. A $p$ value of less than 0.05 was considered significant. The experiments presented are representative of at least two separate experiments.

\section{Results}

Molecular cloning of rat PPAR 1 and $\gamma 2 c D N A s$. Figure 1 shows the nucleotide and deduced amino acid sequences of the full-length rat PPAR $\gamma 1$ and $\gamma 2$ cDNAs. The rat PPAR $\gamma 2$ cDNA $(+1 \sim+1515)$ obtained encoded a 505 amino acid protein. The nucleotides $(+91 \sim+1515)$ of the PPAR $\gamma 2$ cDNA were identical to rat PPAR $\gamma 1$ cDNA $(+1 \sim+1425)$. The nucleotide sequence of rat PPAR $\gamma 2$ cDNA coding region was $90 \%$ and $97 \%$ identical to the human and mouse PPAR $\gamma 2$ cDNAs, respectively $[13,20]$.

Regulation of PPAR $\gamma$ mRNA expression by inflammatory cytokines in rat mature adipocytes. Treatment with $10 \mathrm{nmol} / 1$ of TNF- $\alpha$, IL- $1 \alpha$, IL- $1 \beta$ and LIF caused a $60-70 \%$ reduction of PPAR $\gamma$ mRNA expression $24 \mathrm{~h}$ after the incubation. Further IL- 6 at a concentration of $1 \mathrm{nmol} / \mathrm{l}$ also caused a $58 \%$ reduction and at $10 \mathrm{nmol} / \mathrm{l}$ a maximum reduction of $84 \%$. In contrast, 1 to $10 \mathrm{nmol} / \mathrm{l} \mathrm{TGF}-\beta$ had no effect on PPAR $\gamma$ mRNA regulation (Fig.2A). To examine which isoforms of PPAR $\gamma$ were regulated by inflammatory cytokines, we developed a RT-PCR assay that allows specific evaluation for the expressions of mRNAs encoding the rat PPAR $\gamma 1$ and $\operatorname{PPAR} \gamma 2$ iso-

Fig. 2A-C. Regulation of PPAR $\gamma(\operatorname{PPAR} \gamma 1$ and $\gamma 2)$ mRNA expression by various inflammatory cytokines and intracellular signalling factors in rat mature adipocytes. (A) Mature adipocytes were incubated with various cytokines $(10 \mathrm{nmol} / \mathrm{l}$ of TNF- $\alpha$, IL- $1 \alpha$, IL- $1 \beta$, LIF and TGF- $\beta$ ), ( $1 \mathrm{nmol} / 1$ of IL-6) for $24 \mathrm{~h}$ and their effects on PPAR $\gamma$ mRNA expression were evaluated by northern blot analysis. For the analysis $20 \mu \mathrm{g}$ of total RNA was applied per lane. (B) Mature adipocytes were incubated with various cytokines in the same conditions as in $(\mathbf{A})$. To evaluate the expression of PPAR $\gamma 1$ and PPAR $\gamma 2$ mRNAs RT-PCR, as described "Materials and methods", was used. (C) Mature adipocytes were incubated with $500 \mu \mathrm{mol} / 1 \mathrm{H}_{2} \mathrm{O}_{2}$, $100 \mu \mathrm{mol} / \mathrm{l}$ Lyso-PC, 1 mol/l PMA, 1 mmol/l 8-Br-cAMP and $1 \mathrm{mmol} / \mathrm{l}$ 8-Br-cGMP for $24 \mathrm{~h}$. For the analysis $20 \mu \mathrm{g}$ of total RNA was applied per lane 
TNF- $\alpha$

Time ( h )



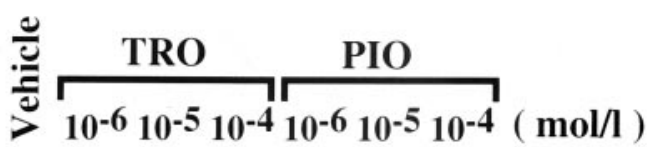

PPAR $\gamma$

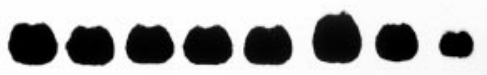

GLUT4

A

\section{$\operatorname{PPAR} \gamma$}



GLUT4

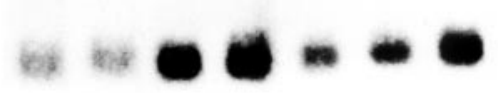

LPL

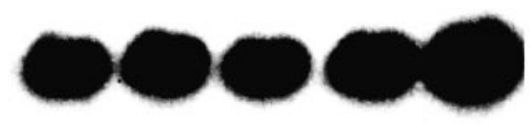

B

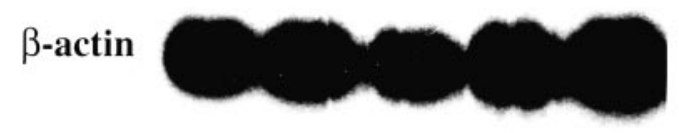

\section{$\beta$-actin}

Fig.4. Effects of thiazolidinediones on $\operatorname{PPAR} \gamma$ and GLUT4 mRNA expressions in rat mature adipocytes. Mature adipocytes were incubated with vehicle and various concentrations of troglitazone (TRO) $\left(10^{-6}\right.$ to $\left.10^{-4} \mathrm{~mol} / \mathrm{l}\right)$ or pioglitazone (PIO) $\left(10^{-6}\right.$ to $\left.10^{-4} \mathrm{~mol} / \mathrm{l}\right)$ and harvested $24 \mathrm{~h}$ after incubation and their effects on $\operatorname{PPAR} \gamma$ mRNA expression were evaluated by northern blot analysis. For the analysis $20 \mu \mathrm{g}$ of total RNA was applied per lane

PPAR $\gamma$ mRNA. This inhibitory action was first observed at $6 \mathrm{~h}$ of incubation and persisted to at least $36 \mathrm{~h}$ after exposure. The expression of PPAR $\gamma$ mRNA did not statistically significantly alter in the control group during the 36-h-incubation period. The GLUT4 mRNA in the control group gradually decreased in a time-dependent manner, and TNF- $\alpha$ also greatly suppressed GLUT4 mRNA expression, compared with the controls (Fig.3A). Treatment with TNF- $\alpha$ (0.1-100 nmol/l) suppressed PPAR $\gamma$ mRNA expression in a dose-dependent fashion. The maximum $(83 \%)$ decrease of PPAR $\gamma$ gene transcript compared with the control occurred with 100 $n m o l / 1$ TNF- $\alpha$. The expression of LPL mRNA remained unchanged after $24 \mathrm{~h}$ of incubation with TNF- $\alpha$ (0.1-100 nmol/l) (Fig. 3B). Similarily mRNA expression of the $o b$ gene did not change (data not shown).

Effects of thiazolidinediones on PPAR $\gamma$ and GLUT4 $m R N A$ expressions in rat mature adipocytes. Troglitazone and pioglitazone caused augmentation of GLUT4 mRNA expression dose-dependently after $24 \mathrm{~h}$ of incubation. The maximum augmentation of GLUT4 mRNA expression compared with the vehicle that was given was $52 \%$ and $38 \%$ by $10^{-4} \mathrm{~mol} / 1$ of troglitazone and pioglitazone, respectively. In contrast, $10^{-6}$ to $10^{-4} \mathrm{~mol} / \mathrm{l}$ of troglitazone or pioglitazone exerted no effect on PPAR $\gamma$ mRNA expression $24 \mathrm{~h}$ after treatment (Fig.4). 
Interaction of thiazolidinediones and TNF- $\alpha$ on PPAR $\gamma$ and GLUT4 $m R N A$ expressions in rat mature adipocytes. To explore the possible interaction of thiazolidinediones and TNF- $\alpha$ on PPAR $\gamma$ expression, we examined the effect of the simultaneous treatment with thiazolidinediones and TNF- $\alpha$ on PPAR $\gamma$ mRNA expression. Troglitazone $\left(10^{-6}\right.$ to $\left.10^{-4} \mathrm{~mol} / \mathrm{l}\right)$ or pioglitazone $\left(10^{-5}\right.$ to $\left.10^{-4} \mathrm{~mol} / \mathrm{l}\right)$ attenuated the inhibitory action of $10 \mathrm{nmol} / \mathrm{l}$ of TNF- $\alpha$ on PPAR $\gamma$ mRNA expression $24 \mathrm{~h}$ after the stimulation $(p<0.05$ or $p<0.01)$. The suppression of this expression caused by $10 \mathrm{nmol} / \mathrm{l} \mathrm{TNF}-\alpha$ was reversed approximately $60 \%$ and $55 \%$ by treatment with $10^{-4} \mathrm{~mol} / 1$ troglitazone and $10^{-4} \mathrm{~mol} / \mathrm{l}$ pioglitazone, respectively. Similar to the PPAR $\gamma$ mRNA expression, thiazolidinediones (troglitazone or pioglitazone) also attenuated the inhibitory action of $10 \mathrm{nmol} / \mathrm{l} \mathrm{TNF}-\alpha$ on GLUT4 mRNA expression $24 \mathrm{~h}$ after the incubation. The suppression of GLUT4 mRNA expression caused by $10 \mathrm{nmol} / \mathrm{l} \mathrm{TNF}-\alpha$ was reversed approximately $70 \%$ and $60 \%$ by treatment with $10^{-4} \mathrm{~mol} / \mathrm{l}$

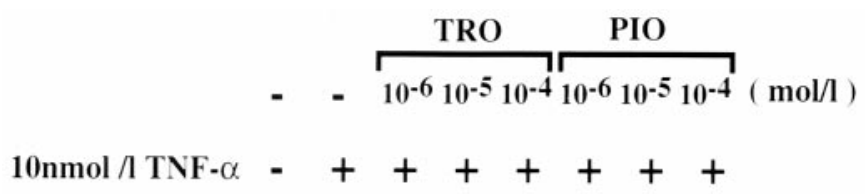

PPAR $\gamma$

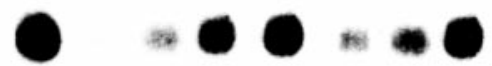

GLUT4

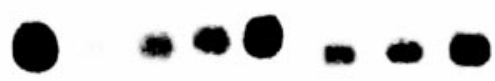

$\beta$-actin

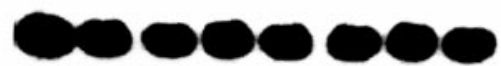

A



$10 \mathrm{nmol} / \mathrm{TNF}-\alpha$ :

thiazolidinediones:
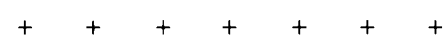

B troglitazone and $10^{-4} \mathrm{~mol} / \mathrm{l}$ pioglitazone, respectively (Fig. 5A,B). The expression of rat TNF- $\alpha$ receptor did not apparently alter with the treatment of TZD and TNF- $\alpha$ (Fig. 6).

Effect of thiazolidinediones and TNF- $\alpha$ on insulinstimulated 2-deoxyglucose uptake in rat mature adipocytes. To investigate the relevance of the regulation of PPAR $\gamma$ mRNA expression by TNF- $\alpha$ and thiazolidinediones, we examined the effects of both on insulin-stimulated glucose uptake under the same experimental conditions as described above. Rat mature adipocytes were incubated in insulin-free media for $24 \mathrm{~h}$ with $10 \mathrm{nmol} / \mathrm{l} \mathrm{TNF}-\alpha$ alone or in the presence of $10^{-4} \mathrm{~mol} / \mathrm{l}$ troglitazone. Insulin-stimulated 2-deoxyglucose uptake was then measured. Insulin caused a $4.2 \pm 0.5$-fold increase of 2-deoxyglucose uptake. Incubation of cells with troglitazone alone had no effect on insulin stimulation for 2-deoxyglucose uptake compared with the control $(4.1 \pm 0.6$-fold increase to the basal condition). When the cells were incubated with TNF- $\alpha$ alone, insulin-stimulated 2-deoxyglucose uptake was attenuated compared with the control $(1.5 \pm 0.3$-fold increase $)(p<0.01)$. In contrast, when the cells were coincubated with TNF- $\alpha$ and troglitazone, insulin stimulated glucose uptake by $3.2 \pm 0.4-$ fold. Thus troglitazone restored the suppressive ef-

Fig. 5A,B. Interaction of thiazolidinediones and TNF- $\alpha$ on PPAR $\gamma$ mRNA or GLUT4 mRNA expression. (A) Mature adipocytes were simultaneously treated with various doses of thiazolidinediones [troglitazone (TRO) or pioglitazone (PIO) $10^{-6}$ to $10^{-4} \mathrm{~mol} / \mathrm{l}$ ] or $10 \mathrm{nmol} / \mathrm{l} \mathrm{TNF}-\alpha$ or both for $24 \mathrm{~h}$ and their effects on PPAR $\gamma$ and GLUT4 mRNA expressions were evaluated by northern blot analysis. Representative results of northern blot analyses. (B) Quantitative measurements of PPAR $\gamma$ or GLUT4 mRNA expression after treatment with thiazolidinediones (TRO or PIO $10^{-6}$ to $10^{-4} \mathrm{~mol} / \mathrm{l}$ ) and either vehicle or $10 \mathrm{nmol} / \mathrm{l}$ TNF- $\alpha$. Bars represent the means \pm SEM $(n=5)$. $* p<0.05$ and $* * p<0.01$ compared with corresponding control values

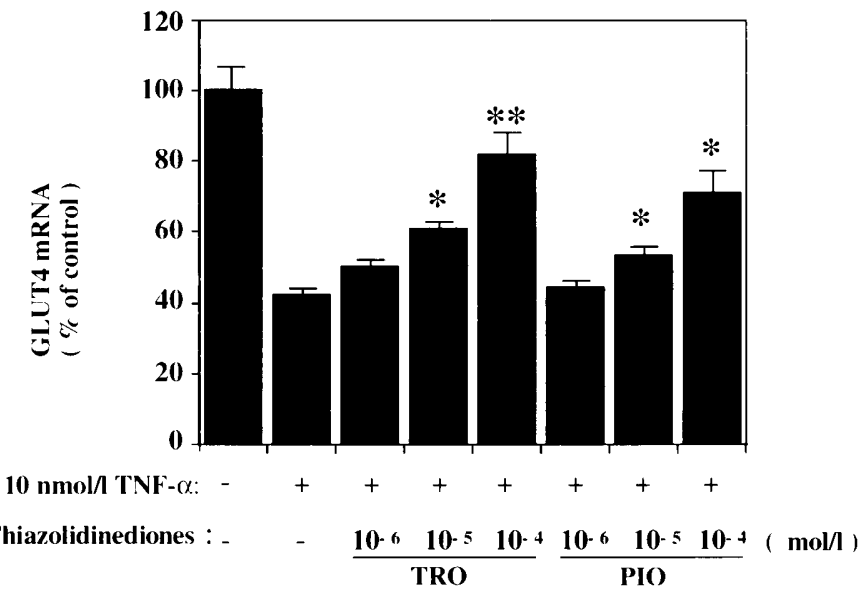




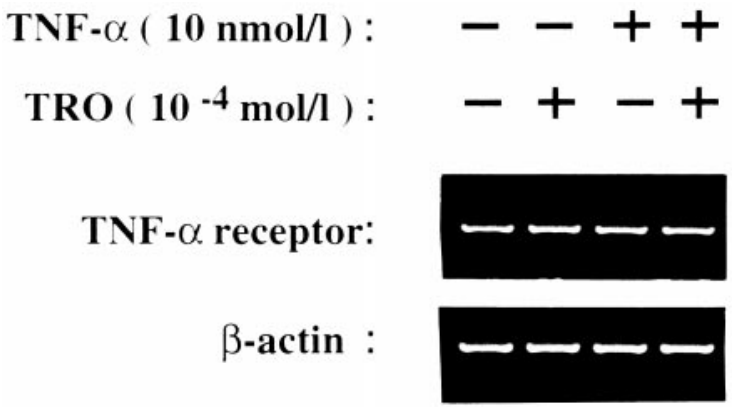

Fig. 6. Effects of thiazolidinediones and TNF- $\alpha$ on TNF- $\alpha$ receptor mRNA expression in rat mature adipocytes. After a 24-h incubation with $10 \mathrm{nmol} / \mathrm{l} \mathrm{TNF}-\alpha$ or $10^{-4} \mathrm{~mol} / \mathrm{l} \mathrm{TRO}$, their effects on TNF- $\alpha$ receptor $\mathrm{mRNA}$ expression were evaluated by RT-PCR analysis

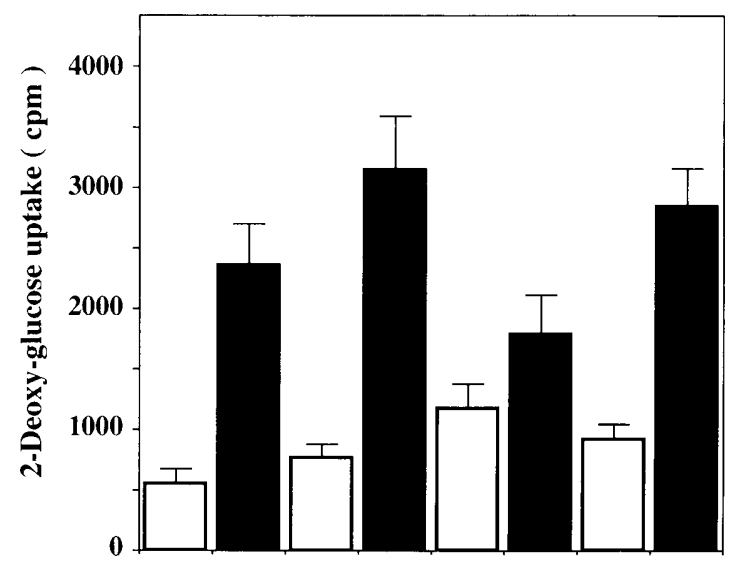

$\mathrm{TNF}-\alpha(10 \mathrm{nmol} / \mathrm{l}):-\rightarrow-++$ TRO $\left(10^{-4} \mathrm{~mol} / \mathrm{l}\right):-\infty++-+$

Fig. 7. Effects of thiazolidinediones and TNF- $\alpha$ on basal and insulin-stimulated 2-deoxyglucose uptake in rat mature adipocytes. After a 24-h preincubation with $10 \mathrm{nmol} / \mathrm{l} \mathrm{TNF}-\alpha$ or $10^{-4} \mathrm{~mol} / \mathrm{l}$ troglitazone (TRO) or both, 2-deoxyglucose uptake was measured with or without $30-\mathrm{min}$ stimulation of $10^{-7} \mathrm{~mol} / \mathrm{l}$ insulin. Data are presented as means \pm SEM of three experiments in triplicate. $\square$ without insulin stimulation, $\square$ with insulin stimulation

fect of TNF- $\alpha$ on insulin-stimulated glucose uptake $(p<0.01)$ (Fig. 7).

\section{Discussion}

Peroxisome proliferator-activated receptors are a family of nuclear receptors comprising three subtypes of designated isoforms, $\operatorname{PPAR} \alpha, \operatorname{PPAR} \gamma$ and $\operatorname{PPAR} \delta$ (also termed PPAR $\beta$, FAAR, or NUC- 1 ) with different and specific tissue distributions [21]. The isoform $\operatorname{PPAR} \gamma$ is a relatively newly discovered member of the PPAR family that has been suggested to be involved in the regulation of not only adipocyte differ- entiation but also lipid metabolism and insulin action. Recent studies showed that the insulin-sensitizing thiazolidinedione class of compounds are synthetic ligands for PPAR $\gamma$ and there seems to be a close relation between the potency of various thiazolidinediones to stimulate PPAR $\gamma$ and their anti-diabetic action [22]. Although a large number of experimental rat models of obesity and insulin resistance have been used to study the pathogenesis, therapy and prevention of diabetes [23], molecular cloning of PPAR $\gamma 1$ and $\gamma 2 \mathrm{cDNAs}$ have been reported only in mice and humans $[13,20]$. In our study, we succeeded in isolating and determining the sequence of rat PPAR $\gamma 1$ and $\gamma 2$ cDNAs. Nucleotide and deduced amino acid sequences analysis showed that the rat PPAR $\gamma 1$ and $\gamma 2$ proteins are 475 and 505 amino acid polypeptides, respectively, with putative signal sequences. The structure of the rat PPAR $\gamma 1$ and $\gamma 2$ proteins explained in this study are highly homologous to those of the mouse and human PPAR $\gamma 1$ and $\gamma 2$ proteins. These observations indicate that the structure of rat PPAR $\gamma 1$ and $\gamma 2$ proteins are evolutionarily conserved among species.

In our study, using rat mature adipocytes, we examined the effect of inflammatory cytokines on the regulation of rat $\operatorname{PPAR} \gamma$ mRNA expression, and moreover investigated the interaction of thiazolidinediones and TNF- $\alpha$, which is one of the best characterized inflammatory cytokines produced in adipocytes and has been suggested as having a role in insulin resistance [3].

In this study, inflammatory cytokines such as TNF- $\alpha$, IL- $1 \alpha$, IL- $1 \beta$, IL- 6 and LIF potently induced down regulation of PPAR $\gamma$ mRNA expression in rat mature adipocytes. The isoforms $\operatorname{PPAR} \gamma 1$ and PPAR $\gamma 2$ were shown to be similarly reduced by inflammatory cytokines. Time-dependent and concentration-dependent reduction in PPAR $\gamma$ expression by TNF- $\alpha$ in mature adipocytes is consistent with a recent report on 3T3L1 adipocytes [24], which are a heteroploid cell line derived originally from mouse embryonic fibroblasts. It has also been reported that infusion of TNF- $\alpha$ into mice in vivo resulted in decreased PPAR $\gamma$ mRNA expression [25]. A recent study showed that infusion of rats with TNF- $\alpha$ resulted in a pronounced insulin resistance as measured by peripheral glucose disposal and hepatic glucose uptake [26]. Moreover, neutralization of endogenous TNF- $\alpha$ by TNF- $\alpha$ receptor-IgG fusion protein improves peripheral insulin sensitivity in obese rats [27]. Thus, TNF- $\alpha$ is considered to be the most probable candidate cytokine related to insulin resistance. In addition, previous studies have also shown that IL-1, IL-6, and LIF concentrations are increased in the sera of patients with infectious diseases, cancer and acquired immuno deficiency syndromes, in which insulin action is impaired [2, 6]. Infusions of IL-1, IL6 into rats have been shown to cause suppression of 
peripheral glucose uptake $[4,8]$. Thus, IL-1, IL-6 and LIF could be other candidates for causing the development of insulin resistance in these diseases. In this study, we showed that some of the inflammatory cytokines, including TNF- $\alpha$, could reduce PPAR $\gamma$ mRNA expression in the adipocytes. We, therefore, suggest that the decrease in both PPAR $\gamma 1$ and PPAR $\gamma 2$ expressions might be the cause of insulin resistance in wasting syndromes in which inflammatory cytokines have a central role. It has been, however, recently shown that the adipose expression of PPAR $\gamma$ mRNA is increased in human obesity [28]. Thus, insulin resistance in inflammation may not be regulated similarly to insulin resistance in obesity and Type II diabetes.

We also examined the effects of intracellular signalling molecules, such as $\mathrm{H}_{2} \mathrm{O}_{2}$, Lyso-PC or PMA on PPAR $\gamma$ expression, and we showed that PPAR $\gamma$ mRNA expression was suppressed considerably by $\mathrm{H}_{2} \mathrm{O}_{2}$, Lyso-PC or PMA. Recent epidemiological and clinical evidence that hyperglycaemia has a role in the development of insulin resistance (glucose toxicity) has been reported [29]. Several laboratories have shown that increased plasma and tissue glucose concentrations could be one of the important sources of the increased oxygen-derived free radicals seen in diabetic patients $[30,31]$. Glucose can be oxidized to generate free radicals and $\mathrm{H}_{2} \mathrm{O}_{2}$. Lyso-PC is also generated during the process of oxidative modification. Furthermore, it was reported that pharmacologic vitamin E (antioxidant) supplementation in patients with Type II diabetes improves insulin resistance [32]. Although in another series of our experiments, exposure to high glucose $(20 \mathrm{mmol} / \mathrm{l})$ for $24 \mathrm{~h}$ showed only a tendency to decrease PPAR $\gamma$ mRNA expression (Tanaka et al. unpublished data), suppression of PPAR $\gamma$ mRNA expression by $\mathrm{H}_{2} \mathrm{O}_{2}$ or Lyso-PC observed in the present study can be related to insulin resistance in hyperglycaemia.

It has been recently reported that insulin increases production of $\mathrm{H}_{2} \mathrm{O}_{2}$ in adipocytes. Exposure of human adipocytes to increasing concentrations of insulin $\left(10^{-11}\right.$ to $\left.10^{-7} \mathrm{~mol} / \mathrm{l}\right)$ led to a dose-dependent increase in $\mathrm{H}_{2} \mathrm{O}_{2}$ generation $[33,34]$. There are also several reports that show that $\mathrm{H}_{2} \mathrm{O}_{2}$ is a potent insulin mimicker. Exogenously supplied $\mathrm{H}_{2} \mathrm{O}_{2}$ has been shown to bring about a range of metabolic effects that are similar to those seen with insulin. In rat primary adipocytes, $\mathrm{H}_{2} \mathrm{O}_{2}(0.3-4 \mathrm{mmol} / \mathrm{l})$ stimulated glucose uptake $[35,36]$. It has been therefore proposed that $\mathrm{H}_{2} \mathrm{O}_{2}$ can act as a second messenger for insulin. In our preliminary experiments, treatment with insulin also suppressed PPAR $\gamma$ mRNA expression. Therefore suppression of PPAR $\gamma$ mRNA expression by $\mathrm{H}_{2} \mathrm{O}_{2}$ can be relevant to hyperinsulinaemia associated with insulin resistance.

In this study, we show that thiazolidinediones strongly restored PPAR $\gamma$ mRNA expression that had been suppressed by TNF- $\alpha$. Previous studies showed several antagonizing actions of thiazolidinediones and TNF- $\alpha$, including the adipocyte differentiation in vitro [37, 38]. Moreover, insulin resistance caused by infusion of TNF- $\alpha$ in vivo has been shown to be prevented by treatment with troglitazone [9]. Our results indicate that $\operatorname{PPAR} \gamma$ expression itself is another site of interaction of thiazolidinediones and TNF- $\alpha$. We also show that thiazolidinediones augmented the expression of GLUT4 in the presence and absence of TNF- $\alpha$ in our primary culture adipocytes. This finding is compatible with previous reports using 3T3L1 adipocytes [37, 38]. It has also been reported that thiazolidinediones restore the decreased GLUT4 expression in obese Zucker rat in vivo [39]. We speculate that the effect of thiazolidinediones in returning PPAR $\gamma$ expression to normal observed in our study is related to one of the mechanisms for the restoration of the suppression of GLUT4 expression by thiazolidinediones induced by TNF- $\alpha$. In our study, we showed that the expression of the TNF- $\alpha$ receptor did not appear to change after treatment with thiazolidinediones and TNF- $\alpha$. Thiazolidinediones are not, therefore, considered to influence the action of TNF- $\alpha$ by changing TNF- $\alpha$ receptor expression. In our culture system without TNF- $\alpha$ treatment, an increase of GLUT4 mRNA expression by thiazolidinediones was accompanied by no change of PPAR $\gamma$ mRNA expression. We speculate that $\operatorname{PPAR} \gamma$ mRNA expression is up regulated in the basal condition and we could not detect the augmentation of PPAR $\gamma$ mRNA expression.

The question addressed by our study was whether the amount of PPAR $\gamma$ mRNA affects the amelioration of insulin resistance. We, therefore, examined insulin-stimulated 2-deoxyglucose uptake in adipocytes treated with TNF- $\alpha$ and thiazolidinediones in our experimental conditions. Our results indicate that thiazolidinediones improve the suppression of insulinstimulated glucose uptake by TNF- $\alpha$ in adipocytes where they, in parallel, restore the decreased PPAR $\gamma$ and GLUT4 expressions by TNF- $\alpha$. We suggest that thiazolidinediones may ameliorate insulin resistance in part by restoring the decreased PPAR $\gamma$ and GLUT4 expressions in adipocytes to normal in the situation of TNF- $\alpha$ or other cytokines-related insulin resistance such as cachexia in chronic infection, chronic inflammatory diseases and neoplastic diseases.

In conclusion, we carried out the isolation and sequence determination of rat PPAR $\gamma 1$ and $\gamma 2$ cDNAs. Inflammatory cytokines such as TNF- $\alpha$, IL$1 \alpha$, IL- $1 \beta$, IL- 6 and LIF reduced the expression of rat $\operatorname{PPAR} \gamma$ mRNA. Thiazolidinediones protected the expression of PPAR $\gamma$ and GLUT4 mRNA from decreasing in the presence of TNF- $\alpha$. These findings suggest that the regulation of PPAR $\gamma$ mRNA expression by thiazolidinediones contributes to their antidiabetic mechanism. 
Acknowledgements. We thank Ms. A. Sone, Ms. A. Nonoguchi and Ms. Y. Takada for their excellent secretarial work. This work was supported in part by research grants from the Japanese Ministry of Education, Science and Culture, the Japanese Ministry of Health and Welfare, Smoking Research Foundation and Yamanouchi Foundation for Research on Metabolic Disorders.

\section{References}

1. Costa G (1977) Cachexia: the metabolic component of neoplastic disease. Cancer Res 37: 2327-2335

2. Grunfeld C, Feingold KR (1991) Metabolic effect of tumour necrosis factor and other cytokines. Biotherapy 3: 143-158

3. Hotamisligil GS, Spiegelman BM (1994) Tumor necrosis factora: a key component of the obesity-diabetes link. Diabetes 43 : 1271-1278

4. Ling PR, Bistrian BR, Mendez B, Istfan NW (1994) Effects of systemic infusions of endotoxin, tumour necrosis factor, and interleukin 1 on glucose metabolism in rat: relationship to endogenous glucose production and peripheral tissue glucose uptake. Metabolism 43: 279-284

5. Strassman G, Fong M, Kenney JS, Jacob CO (1992) Evidence for the involvement of interleukin 6 in experimental cancer cachexia. J. Clin Invest 89: 1681-1684

6. Metcalf D, Gearing DP (1989) Fatal syndrome in mice engrafted with cells producing high levels of the leukemia inhibitory factor. Proc Natl Acad Sci USA 86: 5948-5952

7. Zugmaier G, Widing G, Kanbbe C et al. (1991) Transforming growth factor $\beta 1$ induces cachexia and systemic fibrosis without an antitumour effect in nude mice. Cancer Res 51: 3590-3594

8. Rautonen J, Rautonen N, Martin NL, Philip R, Wara DW (1991) Serum interleukin- 6 concentrations are elevated and associated with elevated tumour necrosis factor-alpha and immunogloblin $\mathrm{G}$ and $\mathrm{A}$ concentrations in children with HIV infection. AIDS 5: 1319-1325

9. Miles PDG, Romeo OM, Higo K, Cohen A, Rafaat K, Olefsky JM (1997) TNF- $\alpha$-induced insulin resistance in vivo and its prevention by troglitazone. Diabetes 46: 1678-1683

10. Nolan JJ, Ludvik B, Beerdsen P, Joyce M, Olefsky J (1994) Improvement in glucose tolerance and insulin resistance in obese subjects treated with troglitazone. N Engl J Med 331: 1188-1193

11. Fujiwara T, Yoshioka S, Yoshioka T, Ushiyama I, Horikoshi H (1988) Characterization of a new oral antidiabetic agent CS045: Studies in KK and ob/ob mice and Zucker fatty rats. Diabetes 37: $1549-1558$

12. Lehmann JM, Moore LB, Smith-Oliver TA, Wilkison WO, Willson TM, Kliewer SA (1995) An antidiabetic thiazolidinedione is a high affinity ligand for peroxisome proliferator-activated receptor $\gamma$ (PPAR $\gamma)$. J Biol Chem 270: 12953-12956

13. Tontonoz P, Hu E, Graves RA, Budavari AI, Spiegelman BM (1994) mPPAR $\gamma$ 2: tissue-specific regulator of an adipocyte enhancer. Genes Dev 8: 1224-1234

14. Nishimura H, Saltis J, Habberfield AD et al. (1991) Phosphorylation state of the GLUT4 isoform of the glucose transporter in subfractions of the rat adipose cell: effects of insulin, adenosine, and isoproterenol. Proc Natl Acad Sci USA 88: 11500-11504

15. Ogawa Y, Itoh H, Tamura N et al. (1994) Molecular cloning of the complementary DNA and gene that overexpress the brain natriuretic peptide gene. J Clin Invest 93: 1911-1921

16. Bell GI, Kayano T, Buse JB et al. (1990) Molecular biology of mammalian glucose transporters. Diabetes Care 13: 198-208

17. Masuzaki H, Hosoda K, Ogawa Y et al. (1996) Augmented expression of obese $(\mathrm{ob})$ gene during the process of obesity in genetically obese-hyperglycemic Wistar fatty (fa/fa) rats. FEBS Lett 378: 267-271

18. Himmler A, Maurer-Fogy I, Krönke M et al. (1990) Molecular cloning and expression of human and rat tumour necrosis factor receptor chain (p60) and its soluble derivative, tumour necrosis factor-binding protein. DNA Cell Biol 9: 705-715
19. Stagsted J, Reaven GM, Hansen T, Goldstein A, Olsson L (1990) Regulation of insulin receptor function by a peptide derived from a major histocompatibility complex class I antigen. Cell 62: 297-307

20. Elbrecht A, Chen Y, Cullinan CA et al. (1996) Molecular cloning, expression and characterization of human peroxisome proliferator activated receptor $\gamma 1$ and $\gamma 2$. Biochem Biophys Res Commun 224: 431-437

21. Schoonjans K, Staels B, Auwerx J (1996) The peroxisome proliferator-activated receptors (PPARs) and their effects on lipid metabolism and adipocyte differentiation. Biochem Biophys Acta 1302: 93-109

22. Zhu Y, Qi C, Korenberg JR, Chen XN, Noya D, Rao MS. (1995) Structural organization of mouse peroxisome proliferator-activated receptor $\gamma(\mathrm{mPPAR} \gamma)$ gene: alternative promoter use and different splicing yield two mPPAR $\gamma$ isoforms. Proc Natl Acad Sci USA 92: 7921-7925

23. Johnson PR, Greenwood MRC, Horwitz BA, Stern JS (1991) Animal models of obesity: genetic aspects. Annu Rev Nutr 11: 325-353

24. Zhang B, Berger J, Hu E et al. (1996) Negative regulation of proliferator-activated receptor- $\gamma$ gene expression contributes to the antiadipogenic effects of tumour necrosis factor- $\alpha$. Mol Endocrinol 10: 1457-1466

25. Hill MR, Young MD, Mccurdy CM, Gimble JM (1997) Decreased expression of murine PPAR $\gamma$ in adipose tissue during endotoxemia. Endocrinology 138: 3073-3076

26. Lang CH, Dobrescu C, Bagby GJ (1992) Tumor necrosis factor impairs insulin action on peripheral glucose disposal and hepatic glucose output. Endocrinology 130: 43-52

27. Spiegelman BM, Flier JS (1996) Adipogenesis and Obesity: Rounding out the big picture. Cell 87: 377-389

28. Vidal-Puig AJ, Considine RV, Jimenez-Linan M et al. (1997) Peroxisome proliferator-activated receptor gene expression in human tissues. J Clin Invest 99: 2416-2422

29. Rossetti L, Giaccari A, DeFronzo RA (1990) Glucose toxicity. Diabetes Care 13: 610-630

30. Hunt JV, Dean RT, Wolff SP (1988) Hydroxyl radical production as the cause of protein damage in the experimental glycation model of diabetes mellitus and aging. Biochem J 256: 205-212

31. Ceriello A, Giugliano D, Quatraro A, Lefebvre PJ (1991) Antioxidants show an anti-hypertensive effect in diabetic and hypertensive subjects. Clin Sci (Colch) 81: 739-742

32. Paolisso G, D'Amore A, Giugliano D, Ceriello A, Varricchio M, D’Onofrio F (1993) Pharmacological doses of vitamin E improve insulin action in healthy subjects and non-insulin-dependent diabetic patients. Am J Clin Nutr 57: 650-656

33. Krieger-Brauer HI, Kather H (1992) Human fat cells possess a plasma membrane-bound $\mathrm{H}_{2} \mathrm{O}_{2}$-generating system that is activated by insulin via mechanism bypassing the receptor kinase. $\mathrm{J}$ Clin Invest 89: 1006-1013

34. Krieger-Brauer HI, Medda PK, Kather H (1997) Insulin-induced activation of NADPH-dependent $\mathrm{H}_{2} \mathrm{O}_{2}$ generation in human adipocyte plasma membranes is mediated by Gai2. J Biol Chem 272: 10135-10143

35. Czech MP, Lawrence JC, Lynn WS (1974) Hexose transport in isolated brown fat cells. J Biol Chem 249: 5421-5427

36. Livingston JN, Gurny PA, Lockwood DH (1977) Insulin-like effects of polyamines in fat cells. J Biol Chem 252: 560-562

37. Ohsumi J, Sakakibara S, Yamaguchi J et al. (1994) Troglitazone prevents the inhibitory effects of Inflammatory cytokines on insulin-induced adipocyte differentiation in 3T3-L1 cells. Endocrinology 135: 2279-2282

38. Szalkowski D, White-Carrington S, Berger J, Zhang B (1995) Antidiabetic thiazolidinediones block the inhibitory effect of tumour necrosis factor-a on differentiation, insulin stimulated glucose uptake, and gene expression in 3T3-L1 cells. Endocrinology 136: $1474-1481$

39. Shimaya A, Noshiro O, Hirayama R, Yoneta T, Niigata K, Sikama H (1997) Insulin sensitizer YM268 ameliorates insulin resistance by normalizing the decreased content of GLUT4 in adipose tissue of obese Zucker rats. Euro J Endocrinol 137: 693-700 